\title{
Memutus Rantai Penularan Covid 19 Dengan Penyemprotan Desinfektan Pada Rumah Warga Kebun Duren Cilodong Depok
}

\author{
${ }^{1 *}$ Slamet Wahyuni, ${ }^{2}$ Muhamad Hedy, ${ }^{3}$ Umar Tauhid, ${ }^{4}$ Wibowo, ${ }^{5}$ Yulianta, \\ 6Nur Iman Duta Waskita \\ Sekolah Tinggi Ilmu Ekonomi Hidayatullah, Depok, Indonesia \\ *slamet.wahyudi@stiehidayatullah.ac.id
}

\begin{abstract}
Abstrak
Tri Dharma Perguruan Tinggi bukan hanya menjadi tanggung jawab mahasiswa. Seluruh dosen (pendidik), serta orang - orang yang terlibat dalam proses pembelajaran ( sivitas akademika) memiliki tanggung jawab yang sama. Salah satu bentuk pengabdian masyarakat ini dituangkan dalam bentuk Kuliah Kerja Nyata (KKN) yang dilakukan STIE Hidayatullah Depok di tengah masyarkat pada umumnya, tujuan dari Kuliah kerja nyata (KKN) ini adalah untuk mengimplemntasikan ilmu yang sudah didapatkan selalama masa perkulihan, dalam hal ini mahsiswa STIE Hidaytullah Depok bekerja sama dengan warga yang ada diwilayah tersebut untuk melakukan kegiatan penyemprotan cairan desinfekatan dalam memutus rantai penularan virus covid-19, dengan adanya kegiatan ini diharapkan daapt membantu pememrintah dalam menangani virus yang sedang mewabah dimasyarakat.
\end{abstract}

Kata Kunci: KKN, Desinfektan, virus covid-19

\begin{abstract}
The Tri Dharma of Higher Education is not only the responsibility of students. All lecturers (educators), as well as people involved in the learning process (academics) have the same responsibility. One form of community service is expressed in the form of Real Work Lectures (KKN) conducted by STIE Hidayatullah Depok in the midst of society in general, the purpose of this real work lecture (KKN) is to implement the knowledge that has been obtained during the study period, in this case students STIE Hidaytullah Depok cooperates with residents in the area to carry out activities of spraying disinfectant liquids to break the chain of transmission of the covid-19 virus, with this activity it is hoped that this activity can help the government in dealing with the virus that is endemic in the community.
\end{abstract}

Key Word: KKN, Desinfektan, virus covid-19

\section{PENDAHULUAN}

Pengabdian masyarakat merupakan bagian integral tri dharma perguruan tinggi yang dalam pelaksanaannya tidak terlepas dari dua dharma yang lain serta melibatkan segenap sivitas akademik: yaitu dosen, mahasiswa, tenaga kependidikan serta alumni. Sesuai dengan Tri Dharma perguruan tinggi yang ketiga yaitu pengabdian kepada masyarakat, maka merupakan sebuah tanggung jawab dari seseorang yang berstatus mahasiswa atau alumni setelah menyelesaikan tugas belajar di kampus adalah untuk mentransformasikan, dan mengaplikasikan ilmu pengetahuan yang telah didapatkan dari dalam kampus Melalui pengabdian masyarakat.

STIE Hidayatullah Depok hadir ditenggah-tengah masyarakat bangsa indonesia, telah menyelangarakan kolaborasi pengabdian masyarakat yaitu dengan bekerja sama melakukan penyemprotan cairan desinfektan untuk mencegah mewabahnya penularan dari virus covid 19 . Salah satu cara memutus rantai penularan Covid-19 adalah dengan menjaga kebersihan dengan membunuh virus Covid-19 sebelum ia menginfeksi manusia. Berbagai cara diantaranya adalah 
menggunakan antiseptik untuk membasuh tangan dan bagian tubuh, dan disinfektan yang disemprotkan atau diusapkan pada berbagai benda mati yang mungkin terpapar virus.

Penyakit corona virus 2019 atau Corona Virus Disease-19 (COVID-19) adalah infeksi saluran pernapasan yang disebabkan oleh jenis virus corona. Nama lain dari penyakit ini adalah Severe Acute Respiratory Syndrome Coronavirus-2 (SARS-COV2 Pada tanggal 11 Maret 2020, Organisasi Kesehatan Dunia atau World Health Organization (WHO) mendeklarasikan penyebaran COVID-19 dikategorikan sebagai pandemi. Menyebarnya wabah COVID-19 ini hingga ke wilayah Indonesia, tentu sangat mengkhawatirkan semua pihak.

Seperti dapat dicermati dari pengalaman beberapa negara serta wilayah lain, penangangan COVID-19 tidak mungkin dapat dilakukan oleh Pemerintah semata. Dibutuhkan keterlibatan terpadu dari semua pihak, termasuk Pemerintah, pihak swasta dan dunia usaha, perguruan tinggi (PT), serta masyarakat. Salah satu wadah untuk mengaplikasikan program pengabdian ini adalah program Praktek Kuliah Kerja nyata (KKN) yang didalam prakteknya mahasiswa STIE Hidayatllah Depok melakukan aksi penyemprotan desinfektan disekitaran perumahan warga kebun duren, Kalimulya, Depok.

\section{METODE}

Metode pelaksanaan ini dilakukan dengan observasi lapangan dan koordinasi dengan mitra. Metode kegiatan ini adalah menyemprotkan cairan desinfektan diarea sekitar perumahan warga baik itu yang ada di dalam ruangan ataupun yang diluar ruangan yang dapat menjadi instrumen penularan virus covid 19.

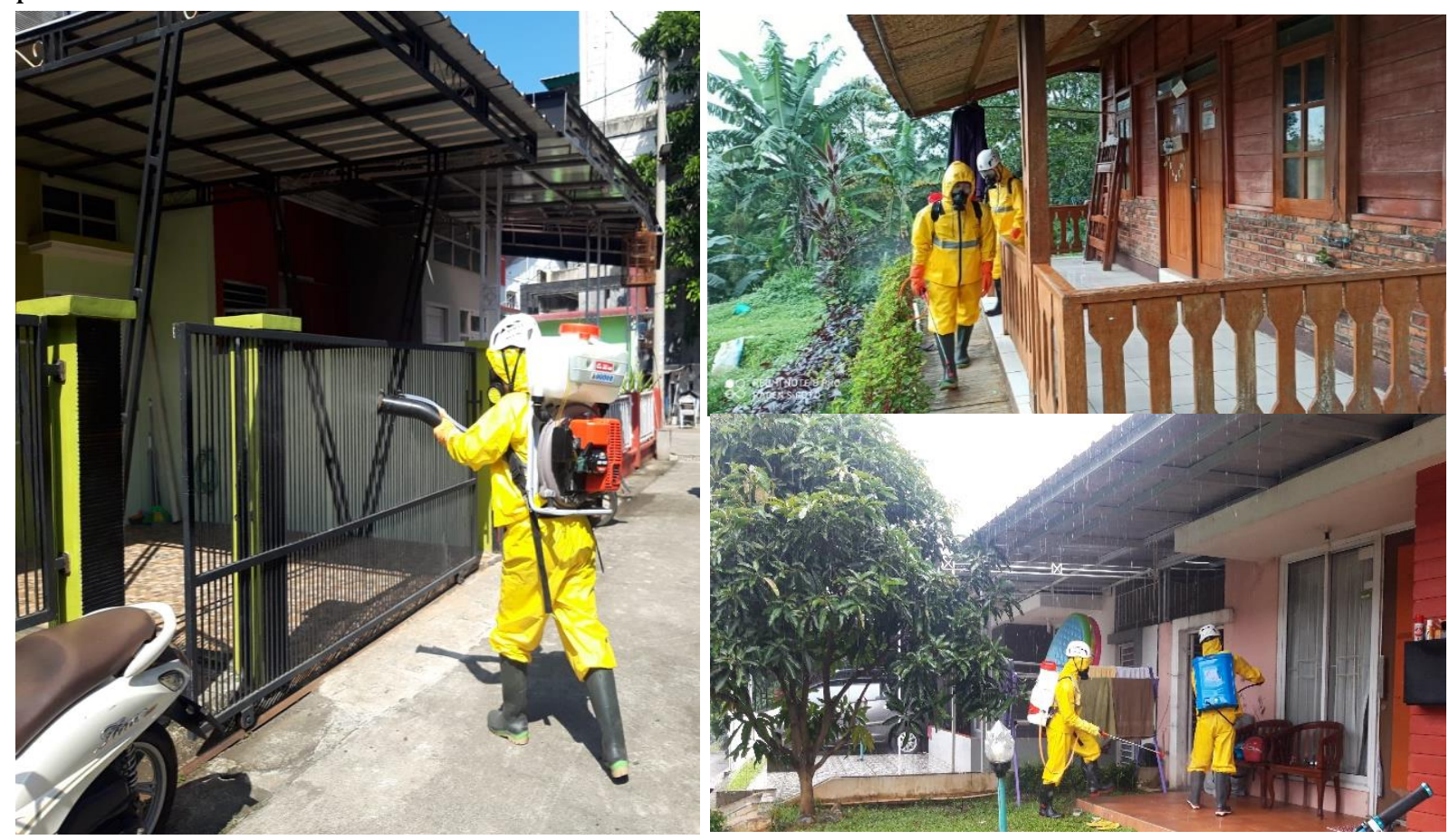

Gambar 1. Penyemprotan cairan desinfektan di area perumahan warga kebun duren, Kalimulya, Cilodong Depok.

Gambar tersebut adalah gambar proses penyemprotan cairan desinfektan diarea perumahan warga yang terdampak pandemi covid 19 di area kebun Duren, Cilodong, Depok. Penyemprotan ini adalah salah satu implementasi kegiatan Pengabdian kepada masyarakat (PKM) yang bertujuan untuk membantu pemerintah secara umum dan masyarakat secara khusus dalam mencegah penularan virus covid 19 disekitaran perumahan warga. 


\section{HASIL DAN PEMBAHASAN}

Saat ini kita masih menghadapi tantangan yang mengharuskan beradaptasi dengan situasi pandemi Corona Virus Disease 2019 (COVID-19). Corona Virus Disease-19 adalah virus yang menyerang sistem pernapasan dan bisa menyebabkan gangguan ringan pada sistem pernapasan, infeksi paru-paru yang berat, hingga kematian. Covid-19 dapat menular dari manusia ke manusia melalui percikan (droplet) dari penderita yang bersin atau batuk dan kontak erat dengan penderita atau kontak dengan permukaan dan benda yang terkontaminasi. Covid-19 masuk ke tubuh melalui mata, hidung, dan mulut lewat tangan yang terkontaminasi virus.

Penerapan protokol kesehatan menjadi kunci penting pencegahan penyebaran COVID-19. Cara itu bisa dimulai dari kedisiplinan di dalam rumah, terutama jika salah satu anggota keluarga aktif beraktifitas di luar rumah. Kesadaran dan peran seluruh anggota keluarga untuk saling melindungi satu sama lain dengan menerapkan protokol pencegahan penyebaran COVID-19 sangatlah penting. Oleh karena itu perlu adaptasi baru yaitu dengan Penerapan 3M untuk pencegahan Covid-19 dapat dilakukan dengan Memakai masker, Mencuci tangan, Menjaga jarak dan menghindari kerumunan. Kemudian mencegah penularan virus covid-19 yaitu dengan melakukan penyemprotan cairan desinfektan.

Meskipun pada saat ini sudah ditemukanya vaksin dari virus covid-19 akan tetapi virus Covid-19 diprediksi akan memperpanjang masa pandemi, sehingga masyarakat harus bersiap dengan keseimbangan baru dengan menerapkan prinsip pola hidup yang lebih bersih dan sehat merupakan kunci dalam menekan penularan COVID-19 pada masyarakat, sehingga diharapkan wabah COVID-19 dapat segera berakhir.

Dalam hal ini Masyarakat memiliki peran penting dalam memutus mata rantai penularan COVID-19 agar tidak menimbulkan sumber penularan baru pada tempat-tempat dimana terjadinya interaksi antar manusia dan berkumpulnya banyak orang. Masyarakat harus dapat beraktivitas kembali dalam situasi pandemi COVID-19 dengan beradaptasi pada kebiasaan baru yang lebih sehat, lebih bersih, dan lebih taat, yang dilaksanakan oleh seluruh komponen yang ada di masyarakat.

Melihat kondisi diatas tidak ada alasan bagi semua elemen masyarakat untuk saling tolongmenolong dan bekerja sama dalam mencegah mewabah covid-19. Dalam Alqur'an disebutkan bahwa: "Sesungguhnya orang-orang mukmin itu bersaudara, karena itu damaikanlah antara saudaramu (yang berselisih) dan bertakwalah kepada Allah agar kamu mendapat rahmat ".(Q.S AlHujurat: 10). Dalam surat yang lain diperintahkan untuk salaing tolong menolong." Tolong menolonglah kalian dalam kebaikan dan takwa, dan janganlah kalian tolong menolong dalam perbuatan dosa dan pelanggaran. (Al-Maidah ayat 2).

Juga dalam sebuah Hadits disebutkan: "Barang siapa melapangkan seorang mukmin dari satu kesusahan dunia, Allah akan melapangkannya dari salah satu kesusahan di hari kiamat. Barang siapa meringankan penderitaan seseorang, Allah akan meringankan penderitaannya di dunia dan akhirat. Barang siapa menutupi (aib) seorang muslim, Allah akan menutupi (aib)nya di dunia dan akhirat. Allah akan menolong seorang hamba selama hamba itu mau menolong saudaranya." (HR. Muslim).

Sehubungan dengan pemaparan diatas dalam hal ini segenap civitas akademik STIE Hidayatullah Depok Bersama dengan semua elemen masyarakat, turut ikut andil dalam penanganan pandemi melalui penyemprotan cairan desinfektan yang diharapkan dapat menjadi pemutus rantai penularan virus covid-19. 


\section{PENUTUP}

\section{KESIMPULAN}

Dengan adanya tuntutan pola hidup baru diharapkan kepada seluruh elemen masyarakat untuk selalu mematuhi kebijakan yang telah ditetapkan pemerintah dalam mengantisipasi virus pandemi covid-19 ini, dan juga sebagai faktor pendukung berjalanya anjuran pemerintah untuk semua masyarakat dapat beupaya bekrja sama untuk melakukan pencegahan penularan virus covid-19.

\section{SARAN}

Berdasarkan bebrapa penjelasan yang telah diuraikan oleh penulis diatas, maka ada beberapa saran yang bisa diterapkan diantaranya adalah:

1. Menerapkan pola hidup sehat yaitu salah satunya dengan Penerapan 3M untuk pencegahan Covid-19 dapat dilakukan dengan Memakai masker, Mencuci tangan, Menjaga jarak dan menghindari kerumunan.

2. Mencegah penularan virus dengan memutus rantai penularanya dilakukan dengan menyemprotkan cairan desinfektan.

\section{DAFTAR PUSTAKA}

Affandi, A., et al. (2020). Optimization of MSMEs Empowerment in Facing Competition in the Global Market during the COVID-19 Pandemic Time. Systematic Reviews in Pharmacy, 11(11), 1506-1515.

Harirah, Z., \& Rizaldi, A. (2020). Merespon Nalar Kebijakan Negara Dalam Menangani Pandemi Covid 19 Di Indonesia.Jurnal Ekonomi dan Kebijakan Publik Indonesia,7(1).

http://ikd.ugm.ac.id/halaman-9-pengabdian-masyarakat.html

https://farmasi.ugm.ac.id/id/cara-penggunaan-disinfektan-yang-tepat-untuk-mencegahpenyebaran-covid-19/

https://kesehatan.jogjakota.go.id/berita/id/212/sosialisasi-protokol-kesehatan-pencegahancovid-19-di-kota-yogyakarta/

NUGROHO, ISFAUZI HADI And YULIANTO, DEMA (2020) Penerapan Disiplin Protokol Kesehatan di Era Kenormalan Baru pada Dunia PAUD. Jurnal al-Hikmah, 8 (1). pp. 150-156.

Rothan HA, Byrareddy SN. The epidemiology and pathogenesis of coronavirus disease (COVID19) outbreak. J Autoimmun. 2020; published online. 